\title{
Induced pluripotent stem cells are Japanese brand sources for therapeutic cells to pretrial clinical research
}

\section{Rupendra Shrestha ${ }^{1,2,3, *}$

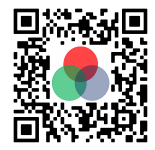

Use your smartphone to scan this QR code and download this article
${ }^{I}$ Department of Genetics, Albert Einstein College of Medicine, NY 10461, U.S

${ }^{2}$ Department of Ophthalmology and Visual Sciences, Albert Einstein College of Medicine, NY 10461, U.S

${ }^{3}$ Dr. Koirala Research Institute for Biotechnology and Biodiversity, Kathmandu, Nepal

\section{Correspondence}

Rupendra Shrestha, Department of Genetics, Albert Einstein College of Medicine, NY 10461, U.S

Department of Ophthalmology and Visual Sciences, Albert Einstein College of Medicine, NY 10461, U.S

Dr. Koirala Research Institute for Biotechnology and Biodiversity, Kathmandu, Nepal

Email: dph.rupendra@gmail.com

History

- Received: 2020-03-28

- Accepted: 2020-05-24

- Published: 2020-06-08

DOI : 10.15419/psc.v7i1.409

\section{Check for updates}

\section{Copyright}

(C) Biomedpress. This is an openaccess article distributed under the terms of the Creative Commons Attribution 4.0 International license.

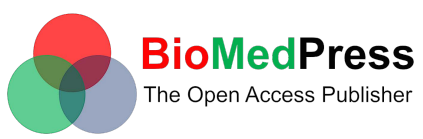

\begin{abstract}
iPSCs are promising and have potential benefits for medical use, understanding human organogenesis, and cell therapy for advanced diseases. iPSCs are derived pluripotent cells which can further differentiate into functional human cell-lineages, such as neuronal, epithelial cells, cardiac cell, immune cell, and blood cells, etc. Thirteen years on, the discovery of iPSC has revolutionized the field of regenerative medicine, and also the number of clinical studies using iPSC has been growing rapidly worldwide. However, Japan is leading the race of iPSC-based studies and clinical trials due to government support. The Japanese government implemented the world's fastest approval system and set to host first pretrial clinical studies using iPSC derived therapeutic products. Also, multinational companies of Japan are investing enormously in iPSC-based research for mobilization of IPSC-derived regenerative products to the research institution globally. This review presents an overview of iPSCs, potential benefits, commercialization of iPSC, iPSC-based pretrial clinical studies, and iPSC biobanking in Japan.
\end{abstract}

Key words: Induced pluripotent stem cells, therapeutic cells, clinical trials, biobank, Japan

\section{INTRODUCTION}

Induced pluripotent stem cells (iPSCs) are reprogrammed pluripotent cells that acquire potential sources of therapeutic cells, such as retinal pigment epithelium (RPE), neurons, and cardiomyocytes, etc. ${ }^{1}$. iPSC technology is a state of changing the plasticity of differentiated cells to a pluripotent state by ectopic expression of defined transcription factors (Oct4, Sox2, Klf4, and c-Myc) ${ }^{2,3}$. These cells were generated from differentiated somatic cells, such as blood cells, fibroblast, keratinocyte, and urine cells, etc. ${ }^{4}$. Also, other differentiated cell types and transcription factors used for generating iPSCs are available in the online database ${ }^{5}$. They have characteristic properties, like self-renewal and pluripotency, that can proliferate indefinitely and differentiate into an amalgam of developmental germ layers ${ }^{2,3}$. These cells widen the range of application in biomedical research, which was used to study organoidogenesis, and generation of clinical-grade therapeutic cells for replacement therapy ${ }^{6,7}$. Such iPSC-derivatives become the hope for many patients to improve their health.

As noted above, the four defined transcription factors were delivered using retroviral vectors to generate iPSCs. Thereafter, various improved delivery methods including integrating system (lentiviral, and inducible lentiviral), excisable system (transposon,
loxP-flanked lentiviral), nonintegrating system (adenoviral, Sendai virus, episomal plasmid), and DNA free system (recombinant proteins system, modified mRNA transfection, microRNA) were used to deliver reprogramming factors ${ }^{8,9}$, as shown in Figure 1. In addition, several small molecules and soluble factors such as valproic acid, sodium butyrate, BIX-01294, SB431542, vitamin C, Y-27632, and PS48 have been used to enhance the efficiency of iPSCs production ${ }^{9}$. The study is based on the analysis of relevant peerreviewed and published literature for this review on iPSCs-derived therapeutic cells. All the information was obtained from the reliable literature sources, such as PubMed, Science Direct, Nature News, institutional websites, and other authenticated public domains. Several search terms like iPSCs, genomic instability, therapeutic cells, clinical trials, and Japan were used to find suitable documents. "Boolean operators" (AND, OR, NOT) were used between search terms to retrieves literature from PubMed. In this review, we primarily focus on the therapeutic potential of iPSC derivatives, iPSC technology commercialization, clinical studies, iPSC biobanking, and ongoing research using iPSCs in Japan.

\section{iPSCs as a source of therapeutic cells}

iPSCs offer a promising platform for cell-based therapy and personalized medicine. It was a breakthrough 


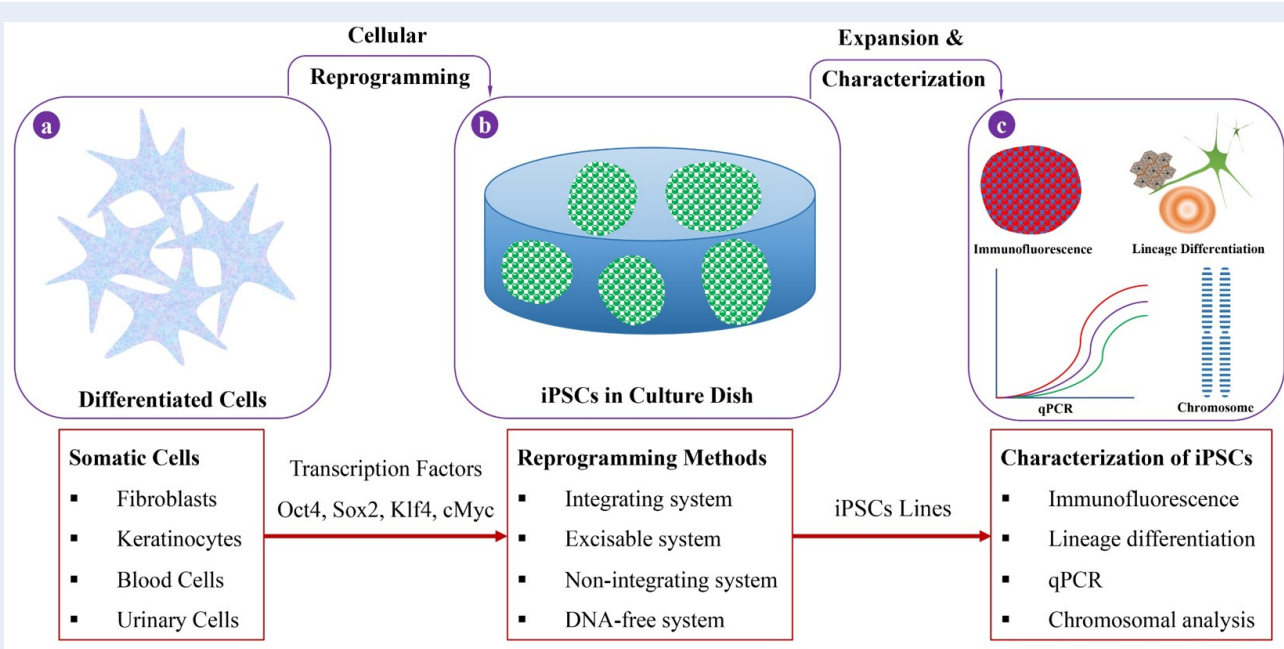

Figure 1: Schematic illustration of iPSC generation and their characterization. (a) Differentiated somatic cells are initial cells that are used for cellular reprogramming, (b) Various improved reprogramming methods used for the efficient delivery of reprogramming transcription factors to create iPSC, and (c) Methods used to characterize iPSC lines which are essential to continue for further differentiation studies.

in the field of regenerative medicine that was discovered by Shinya Yamanaka and his colleagues in $2006^{2}$. His innovation of iPSCs led him to be honored with Nobel Prize in Physiology or Medicine 2012 (jointly awarded with Sir John B Gurdon) ${ }^{10}$. iPSCs derivatives are potential therapeutic cells that overcome the limitation of ethical issues and immune barriers associated with embryonic stem cells (ESCs) ${ }^{11}$. In a decade, iPSC became the brand source of Japan that flourished globally due to its potential benefits in disease modeling, regenerative therapy, drug screening, population health, and basic research ${ }^{7}$. Known that iPSC-derived cells have been gaining high demand for therapeutic use in the clinic, it is essential to determine the genomic integrity that could be associated with forced reprogramming, selective pressure, and cultural adaptation ${ }^{12,13}$. Several studies reported the possibility of recurrent genomic alterations in iPSCs, such as cytogenetic abnormalities and copy number variations ( $\mathrm{CNV}$ ) that raise the potential safety issues ${ }^{14-18}$. However, considerable evidence indicates that genomic heterogeneity in iPSCs was inherited from the parental cells carrying somatic mutations that have a random probability distribution. Such genetic variations are neither due to reprogramming nor does it lead to an increased number of de novo mutations. They reported that observed rare alterations in parental cells existed in low frequencies detected by sequencing-based approaches ${ }^{19,20}$. These indicate iPSC reprogramming is not mutagenic that supports the safety considerations for product development and the therapeutic application of iPSC-derived cells in regenerative medicine, as illustrated in Figure 2. iPSC technology offers several advantages that can be used directly for the study of developmental biology, disease modeling, drug discovery, and cell transplantation ${ }^{9}$. Although iPSCs have benefits in regenerative medicine, they do have some disadvantages, as listed in Table $\mathbf{1}$.

Meanwhile, genomic instability (chromosomal alterations, CNVs, and mutations) in iPSCs are major concern in clinical applications, but the key factors governing the instability is still elusive ${ }^{9,12,18}$. Instability in iPSCs are similar to that seen in cancer cells, which have compromised cell therapy safety ${ }^{21}$. Such transient mutation can be reduced by using starting cell sources from the younger donor, avoiding oncogenic transcription factors, using non-integrating vectors system, chemical induction, and using antioxidants in the culture medium ${ }^{9,12}$. Also, high-resolution SNP genotyping should use to classify mutation pattern, differentiate benign mutations, and those causing tumor formations to mitigate effects of these mutations on cell therapy ${ }^{22}$.

\section{iPSC technology commercialization in Japan}

In a short time, iPSC benefits were well-recognized for medicine in the global community. Thus, iPS Academia Japan, Inc. was established at Kyoto University on 25 June 2008 to govern the licensing of iPSC patents, and then promote iPSCs and related technology transfer to industry for its commercialization ${ }^{23}$. 
Table 1: Advantages and disadvantages of iPSCs in stem cell-based medicine

\begin{tabular}{|c|c|c|}
\hline S.N. & Advantages & Disadvantages \\
\hline 1. & $\begin{array}{l}\text { iPSCs are readily available and have the potential to dif- } \\
\text { ferentiate into therapeutic cells like RPE, neurons, and } \\
\text { cardiomyocytes. }\end{array}$ & $\begin{array}{l}\text { iPSCs generation is time-consuming, expen- } \\
\text { sive, and some transcription factors used in re- } \\
\text { programming are oncogenic. }\end{array}$ \\
\hline 2. & $\begin{array}{l}\text { iPSCs can be differentiated to organoids that closely } \\
\text { mimic the human organs that are inaccessible to inves- } \\
\text { tigate, like retina and brain. }\end{array}$ & $\begin{array}{l}\text { Reprogramming efficiency is low and also de- } \\
\text { pends on the types of somatic cells used for re- } \\
\text { programming. }\end{array}$ \\
\hline 3. & $\begin{array}{l}\text { iPSCs-derived specific cells can be used to screen vari- } \\
\text { ous candidate drugs for personalized medicine. }\end{array}$ & $\begin{array}{l}\text { Viral vector-based reprogramming has the po- } \\
\text { tential to develop tumorigenesis when trans- } \\
\text { planted. }\end{array}$ \\
\hline 4. & $\begin{array}{l}\text { Patient-specific iPSCs can be used to model human ge- } \\
\text { netic diseases. }\end{array}$ & $\begin{array}{l}\text { Forced reprogramming and long-term cultural } \\
\text { adaptation induce genetic mutations in iPSCs. }\end{array}$ \\
\hline 5. & $\begin{array}{l}\text { Like ESCs, iPSCs have no moral and ethical issues as it } \\
\text { is derived from the patient's somatic cells. }\end{array}$ & $\begin{array}{l}\text { Allogenic transplantation of iPSC-derived ther- } \\
\text { apeutic cells causes the rejection of transplants. }\end{array}$ \\
\hline
\end{tabular}

In 2009, the first license agreement was signed with ReproCELL and then with Cellular Dynamics International in 2010 for industrialization of technology to generate clinical-grade iPSC. Later, Fujifilm acquired Cellular Dynamics International (CDI) and invested significantly in stem cells to develop safer and efficient iPSC-based cell therapies ${ }^{23}$. Now, Fujifilm headquartered in Tokyo is the foremost leader in the field of regenerative medicine. Afterward, license agreements have been signed with numerous companies globally that include 110 in Japan, 46 in North America, 34 in Europe and 5 in Asia as of April $2019^{24}$.

The fact that iPSCs could be generated from the adult cells without moral and ethical restrictions, these cells have been showing potential benefits and growing impact in medicine. Also, iPSC-based clinical studies have been receiving growing scientific interest and rapidly increasing in number worldwide. Thus, the commercialization of these cells represents the productive market in the field of regenerative medicine. Knowing the progressive impact on medicine, Center for iPS Cell Research and Application (CiRA) was established in 2008 to hold the intellectual property and to foster iPSC technology. Later, on 1 April 2010, CiRA was recognized as an independent institute at Kyoto University and Nobel Laureate, Shinya Yamanaka was appointed as a director ${ }^{25}$. Currently, CiRA grips basic iPSC technology patents in numerous countries, such as Australia, Canada, China, France, Germany, Ireland, Italy, Japan, Mexico, Singapore, Spain, Sweden, UK, and U.S. etc. ${ }^{26}$. In addition, CiRA promotes the iPSC stock, iPSC-based cell therapy, and personalized medicine using iPS cells. Due to the high demand of iPSC-based clinical studies, the iPS Cell Stock for Regenerative Medicine project was started in 2013. Further, they established the Facility for iPS Cell Therapy (FiT) to support the distribution of clinical-grade iPSC to institutions for developing new medical therapies. Later in February 2017, Japanese pharmaceutical company, Sumitomo Dainippon Pharma Co., LTD. started the construction of manufacturing plant for regenerative medicine and cell therapy to accelerate iPSC research and the advancement of iPSC therapies into the clinic. The Sumitomo Dainippon Manufacturing Plant for Regenerative Medicine \& Cell Therapy (SMaRT) was established in its Central Research Laboratories at Osaka, Japan. The manufacturing plant, which cost around 3.6 billion Yen, was completed on 1 March 2018. There onwards, the plant is engaged in generating iPSC derivatives for the treatment of age-related macular degeneration (AMD), retinitis pigments, spinal cord injury, and Parkinson's disease etc. ${ }^{27}$.

\section{iPSC-based pretrial clinical studies in Japan}

Thirteen years on, safety, efficacy, and potential benefits of iPSC derivatives has been proved in preclinical models. iPSC is an innovation of Japan, now leading for quality commercialization of iPSC-derivatives, and also becoming the world first nation to conduct pretrial clinical studies. Japanese researchers consider iPSC as an alternative source for therapeutic cells and artificial organs for diseases in which human tissues or organs are inaccessible to investigate. Recognizing their discovery and productive market, Japan government amended the Pharmaceutical and Medical Device Act (PMDA) in Nov 2013 opening door for regenerative medicine products. Revised PMDA act accelerated the iPSC-based therapy development by set- 


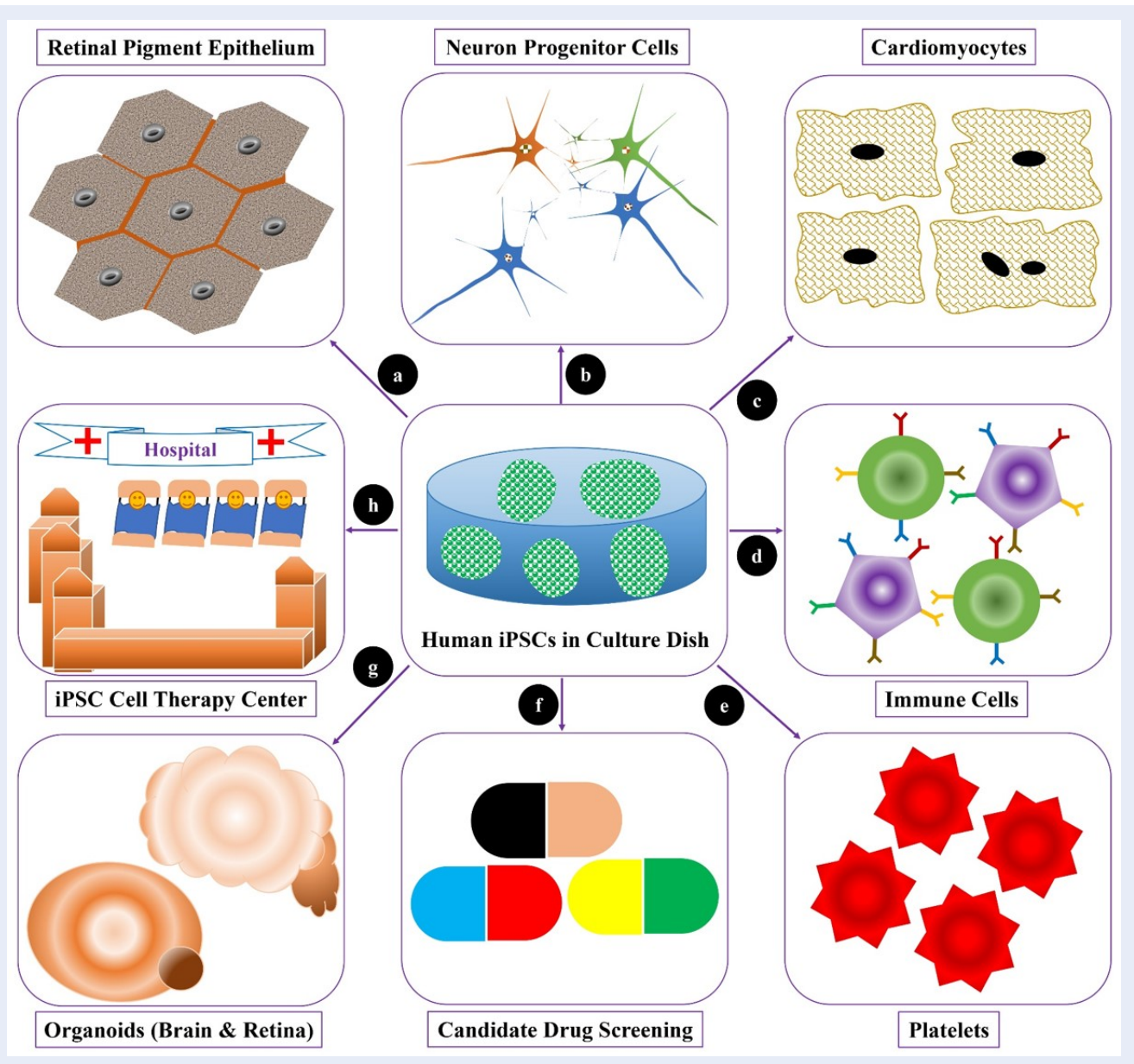

Figure 2: Illustration showing therapeutic benefits of iPSCs in regenerative medicine. Patient-specific iPSCs were generated and further differentiated into a) retinal pigment epithelium, b) neuron progenitor cells, c) cardiomyocytes, d) immune cells, and e) platelets to model as therapeutic cells in various diseases. f) iPSC-derived specific cells can be used for screening the candidate drugs and for personalized medicine. g) iPSCs have been used to generate the three-dimensional tissues (retinal and brain organoids) to model the organogenesis. $\mathbf{h}$ ) clinical-grade iPSC-derived therapeutic cells are used for cell therapy for end-stage diseases.

ting the fastest approval system for clinical trials in the world $^{28-30}$. In Japan, therapeutic cells derived from iPSCs have been transplanted into wet-type AMD and Parkinson's disease, while more clinical studies are planned for other conditions. In recent years, the Japan government is setting to host world's first pretrial clinical studies for several diseases and had approved physician-led clinical trials as listed in Table 2. The country's scientists are now leading the way with clinical translation.

It is obvious that the challenges encounter when closer to clinical trials, but that also leads to the process for scientific discovery. In 2013, Japan took credit for historical movement in the race to develop iPSbased therapies and considered as a landmark year. A panel of Japan's Health Ministry approved the project for autologous transplantation RPE sheets derived from iPSC in patients with wet-type AMD ${ }^{39}$. The project was conducted at RIKEN Center in Kobe, Japan, which was led by Masayo Takahashi of the RIKEN Center for Developmental Biology (CDB). RIKEN is the largest national scientific research institute supported by Japan's Health Ministry and exclusively funded by the Japanese government ${ }^{40,41}$. For the first patient enrolled, iPSC-derived RPE patch was transplanted in September 2014. One-year followup observation showed a good safety profile without significant improvement in visual acuity but stopped the progression of the disease ${ }^{42}$. However, transplant was halted in second patients due to genomic alteration in the patient's iPSC-derived RPE cells, owing to the possible risk of aberrations in DNA copy num- 
Table 2: World's first iPSC-based pretrial clinical studies approved in Japan

\begin{tabular}{|c|c|c|c|c|}
\hline iPSC Derivatives & Disease & $\begin{array}{l}\text { Principal Investiga- } \\
\text { tors }\end{array}$ & Start of the Clinical Trials & References \\
\hline $\begin{array}{l}\text { Retinal Pigment } \\
\text { Epithelium (RPE) }\end{array}$ & $\begin{array}{l}\text { Wet-type age-related } \\
\text { macular degeneration }\end{array}$ & $\begin{array}{l}\text { Masayo Takahashi; } \\
\text { RIKEN Center }\end{array}$ & 12 Sep 2014 Transplanted & 31 \\
\hline $\begin{array}{l}\text { Dopaminergic Pro- } \\
\text { genitors }\end{array}$ & Parkinson's Disease & $\begin{array}{l}\text { Jun Takahashi; } \\
\text { Kyoto University }\end{array}$ & $\begin{array}{l}\text { Oct } 2018 \\
\text { Transplanted }\end{array}$ & 32 \\
\hline Cardiomyocytes & Severe Heart Disease & $\begin{array}{l}\text { Yoshiki Sawa; } \\
\text { Osaka University }\end{array}$ & $\begin{array}{l}16 \text { May } 2018 \\
\text { Approved }\end{array}$ & 33 \\
\hline Platelets & Aplastic Anemia & $\begin{array}{l}\text { Koji Eto; } \\
\text { Kyoto University }\end{array}$ & 21 Sep 2018 Approved & 34 \\
\hline Neural Cells & Spinal Cord Injuries & $\begin{array}{l}\text { Hideyuki Okano; } \\
\text { Keio University }\end{array}$ & 18 Feb 2019 Approved & 35 \\
\hline Corneal Epithelium & Corneal Diseases & $\begin{array}{l}\text { Koji Nishida; } \\
\text { Osaka University }\end{array}$ & $\begin{array}{l}\text { March } 2019 \\
\text { Approved }\end{array}$ & 36 \\
\hline $\begin{array}{l}\text { Natural Killer T } \\
\text { Cells }\end{array}$ & $\begin{array}{l}\text { Head and neck Can- } \\
\text { cers }\end{array}$ & $\begin{array}{l}\text { Haruhiko Koseki; } \\
\text { RIKEN Center }\end{array}$ & $\begin{array}{l}11 \text { Jan } 2019 \\
\text { Planned }\end{array}$ & 37 \\
\hline $\begin{array}{l}\text { Candidate Drug } \\
\text { (Rapamycin) }\end{array}$ & $\begin{array}{l}\text { Fibrodysplasia Ossifi- } \\
\text { cans Progressiva }\end{array}$ & $\begin{array}{l}\text { Junya Toguchida; } \\
\text { Kyoto University }\end{array}$ & $\begin{array}{l}1 \text { Aug } 2017 \\
\text { Clinical Trial }\end{array}$ & 38 \\
\hline
\end{tabular}

bers (deletions) ${ }^{42}$. Surprisingly, new regulation was implemented in regenerative medicine legislation of Japan in November 2014 that state, "the proposal for pretrial clinical study should be submitted from medical but not research institutions". Thus, patient enrollment was immediately halted for RPE cell therapy in 2015. Later in 2017, allogenic HLA-matched iPSCderived RPE cells were transplanted in the second patient $^{43}$. Interestingly, Kyoto Hospital made an official announcement for establishment of special iPSC therapy center with 30-bed ward to conduct clinical studies for testing safety and efficacy of the iPSC therapies on volunteer patients. They aim to finish complete setup by September 2019 and planning to get approval for iPSC-based product by 2020 .

\section{Globalization of Japan iPSC and derivatives}

iPSC-based therapies should be available to global population. Therefore, making availability of quality iPSC and derivatives become commercially important. To move forward with global clinical trials using iPSC-RPE for treatment of AMD, Healios K.K. established a patent license agreement with RIKEN in August 2011. They hold the exclusive worldwide license covering regenerative products that contain iPSC-derived RPE cells. Additionally, Healios establish collaboration with Sumitomo Dainippon Pharma for joint development of new therapies for wet-type AMD in Japan and also with National Eye Institute
(NEI) for dry-type AMD in US/EU ${ }^{44,45}$. Next, Cynata Therapeutic in joint development with Japanese company, Fujifilm received approval from the U.K. and Australia government in September 2016, to begin a clinical trial using allogenic iPSC-derived mesenchymal stem cells (MSCs) for treating graft-versushost disease (GVHD) ${ }^{46}$. The world's first clinical trial of an allogeneic cell product, "CYP-001" derived from iPSC begins in both the U.K. and Australia ${ }^{46}$. In this historic trial, Australian regenerative medicine company is testing product for GVHD ${ }^{47}$. GVHD is a transplant complication, in which the donor's immune T cells (graft) attack the patient's healthy cells or tissues (host) and damage them. iPSCs-derived MSCs were implanted, and two years post-implantation data from all 16 participants are expected to be completed by May 2020 to evaluate the safety and efficacy.

\section{Japan iPSC banking and online database for global population}

Patient-specific iPSCs are becoming challenging due to time-consuming to generate iPSC derivatives from patient somatic cells ${ }^{48}$, and chance of carrying somatic mutation into iPSCs ${ }^{49}$. Such challenges pose risk for missing threshold time for transplantation and effects of mutation inherited from parental cells. So, there is prerequisite of healthy donor for reducing the cost and rapid availability for cell therapy to the patients. To overcome the need of autologous cell 
therapy or immune rejection associated with human leucocytes antigen (HLA) mismatch ${ }^{50}$, CiRA is establishing the iPSC stock for medical use by recruiting the HLA homozygous (HLA-A, -B, and -D.R.) super donors. iPSCs derived from super donor somatic cells reduced the risk of rejection when transplanted in patient with heterozygous HLA for same haplotypes ${ }^{51}$. Currently they have 4 HLA homozygous iPSC lines, which cover $40 \%$ of Japan's population. In addition, using genome editing technology, they estimated to generate 10-12 iPSC lines that will cover more than $90 \%$ of world population. "My iPS cells" project is next in the line to begins from 2025 as disclosed by Yamanaka during his presentation at ISSCR 2019 annual meeting held between 26-29 June 2019 at Los Angeles, US. Interestingly, Akitsu and his colleagues generated HLA-C retained iPSCs by allelespecific genome editing to make immune compatible iPSC that will benefit to most of the global population. First HLA class I pseudo-homozygous iPSCs were generated from HLA heterozygous donors. Then, both allele of HLA-A and HLA-B and mono allele of HLA-C were deleted to retain one HLA-C allele to generated HLA-C retained iPSCs which greatly expand donor compatibility with larger populations ${ }^{52}$. Furthermore, with increase in number for iPSC research in global scenario, several iPSC online databases, such as eagle-I ${ }^{53}$, hPSC ${ }^{\text {reg }} 54$, RIKEN BRC $^{55}$, SKIP ${ }^{56}$ were established. Recently, CiRA professor Wataru Fujibuchi combined all those databases and released Integrated Collection of Stem Cell Bank Data (ICSCB) by MIACARM (Minimum Information About a Cellular Assay for Regenerative Medicine ${ }^{57}$.ICSCB database provides the uniform, accurate and user-friendly data exchange that will facilitate the accelerated access to iPSCs data for research.

\section{CONCLUSIONS}

iPSCs are promising platform for future medicine, such as cell-based therapy for reversing diseases, patient specific-iPSC biobanking to investigate a diverse range of conditions, use of physiologically relevant cells derived from iPSC for drug development \& discovery, and iPSC-derivatives for toxicology screening. Because, iPSC was discovered by the Japanese scientist, the country's researchers working in the field of regenerative medicine consider iPSCs as promising sources for therapeutic cells. Also, the government of Japan supports for the iPSC research, amended the regenerative medicine law for fast approval system for pretrial clinical studies and commercialization of iPSC-related products by holding basic patent licensing from most of the countries. To conclude, the iPSC is a brand source of Japan that provide clinical grade iPSC and related products worldwide. Also, Japanbased companies were investing massive funds in the iPSC-based research and collaborated with multinational companies globally to promote the use of iPSC for clinical trials.

\section{ACKNOWLEDGMENTS}

Due to space limitations, I had to limit the number of citations. I apologize to those authors whose work has not been cited here.

\section{FUNDING}

Not applicable.

\section{AVAILABILITY OF DATA AND MATERIALS}

Not applicable.

\section{ETHICS APPROVAL AND CONSENT TO PARTICIPATE}

Not applicable.

\section{CONSENT FOR PUBLICATION}

Not applicable.

\section{COMPETING INTERESTS}

The authors declare that they have no competing interests.

\section{REFERENCES}

1. Shi $\mathrm{Y}, \mathrm{H} \mathrm{HI}, \mathrm{Wu}$ JC, Yamanaka S. Induced pluripotent stem cell technology: a decade of progress. Nat Rev Drug Discov. 2017;16(2):115-130. PMID: 27980341. Available from: https://doi.org/10.1038/nrd.2016.245; http://www. ncbi.nlm.nih.gov/pubmed/27980341.

2. Takahashi K, Yamanaka S. Induction of pluripotent stem cells from mouse embryonic and adult fibroblast cultures by defined factors. Cell. 2006;126(4):663-676. PMID: 16904174. Available from: https://doi.org/10.1016/j.cell.2006.07.024;http: //www.ncbi.nlm.nih.gov/pubmed/16904174.

3. Takahashi K, Tanabe K, Ohnuki M, Narita M, Ichisaka T, Tomoda $\mathrm{K}$, et al. Induction of pluripotent stem cells from adult human fibroblasts by defined factors. Cell. 2007;131(5):861-872. PMID: 18035408. Available from: https://doi.org/10.1016/j.cell. 2007.11.019; http://www.ncbi.nlm.nih.gov/pubmed/18035408.

4. Raab S, Klingenstein M, Liebau S, Linta L. A comparative view on human somatic cell sources for iPSC generation. Stem Cells Int. 2014;p. 1-12. PMID: 25431601. Available from: https://doi.org/10.1155/2014/768391;http://www. ncbi.nlm.nih.gov/pubmed/25431601.

5. Center of Regenerative Medicine in Barcelona (CMR[B]). Direct reprogramming of human and mouse cells with defined factors;Available from: https://intranet.cmrb.eu/reprogramming/ search1.html.

6. Liu C, Oikonomopoulos A, Sayed N, Wu JC. Modeling human diseases with induced pluripotent stem cells: from $2 D$ to $3 D$ and beyond. Development. 2018;145(5):dev156166. PMID: 29519889. Available from: https://doi.org/10.1242/dev.156166; http://www.ncbi.nlm.nih.gov/pubmed/29519889. 
7. Trounson A, DeWitt ND. Pluripotent stem cells progressing to the clinic. Nat Rev Mol Cell Biol. 2016;17(3):194-200. PMID: 26908143. Available from: https://doi.org/10.1038/nrm.2016. 10;http://www.ncbi.nlm.nih.gov/pubmed/26908143.

8. Shrestha R, Wen YT, Tsai RK. Generation of hiPSC line TCIERi001-A from normal human epidermal keratinocytes. Stem Cell Res. 2019;41:101590. PMID: 31683100. Available from: https://doi.org/10.1016/j.scr.2019.101590;https:// linkinghub.elsevier.com/retrieve/pii/S187350611930220X9.

9. Shrestha R, Wen YT, Tsai RK. Induced pluripotent stem cells and derivative photoreceptor precursors as therapeutic cells for retinal degenerations. Tzu Chi Med J. 2020;32(2):101-112. PMID: 32269941. Available from: https://doi.org/10.4103/tcmj.tcmj_147_19;https://www. ncbi.nlm.nih.gov/pmc/articles/PMC7137374/.

10. The Nobel Prize in Physiology or Medicine 2012. NobelPrize.Org. Nobel Media AB 2019;Available from: https://www. nobelprize.org/prizes/medicine/2012/summary/.

11. Yamanaka S. Patient-specific pluripotent stem cells become even more accessible. Cell Stem Cell. 2010;7(1):1-2. PMID 20621038. Available from: https://doi.org/10.1016/j.stem.2010. 06.009; http://www.ncbi.nlm.nih.gov/pubmed/20621038.

12. Yoshihara M, Hayashizaki Y, Murakawa Y. Genomic instability of iPSCs: challenges towards their clinical applications. Stem Cell Rev Reports. 2017;13(1):7-16. PMID: 27592701. Available from: https://doi.org/10.1007/s12015-016-9680-6; http://www. ncbi.nlm.nih.gov/pubmed/27592701.

13. Mayshar Y, Ben-David U, Lavon N, Biancotti JC, Yakir B, Clark AT, et al. Identification and classification of chromosomal aberrations in human induced pluripotent stem cells. Cell Stem Cell. 2010;7(4):521-531. PMID: 20887957. Available from: https://doi.org/10.1016/j.stem.2010.07.017;http:// www.ncbi.nlm.nih.gov/pubmed/20887957.

14. Hussein SM, Batada NN, Vuoristo S, Ching RW, Autio R, Närvä $E$, et al. Copy number variation and selection during reprogramming to pluripotency. Nature. 2011;471(7336):5862. PMID: 21368824 . Available from: https://doi.org/10.1038/ nature09871;http://www.ncbi.nlm.nih.gov/pubmed/21368824.

15. Taapken SM, Nisler BS, Newton MA, Sampsell-Barron TL, Leonhard KA, McIntire, et al. Karyotypic abnormalities in human induced pluripotent stem cells and embryonic stem cells. Nat Biotechnol. 2011;29(4):313-314. PMID: 21478842. Available from: https://doi.org/10.1038/nbt.1835;http://www.ncbi. nlm.nih.gov/pubmed/21478842.

16. Weissbein U, Plotnik O, Vershkov D, Benvenisty N. Cultureinduced recurrent epigenetic aberrations in human pluripotent stem cells. Clark A, editor. PLOS Genet. 2017:13(8):e1006979. PMID: $28837588 . \quad$ Available from: https://doi.org/10.1371/journal.pgen.1006979;http: //www.ncbi.nlm.nih.gov/pubmed/28837588.

17. Garitaonandia I, Amir H, Boscolo FS, Wambua GK, Schultheisz $\mathrm{HL}$, Sabatini $\mathrm{K}$, et al. Increased risk of genetic and epigenetic instability in human embryonic stem cells associated with specific culture conditions. PLoS One. 2015;10(2):e0118307. PMID: $25714340 . \quad$ Available from: https://doi.org/10.1371/journal.pone.0118307;http: //www.ncbi.nlm.nih.gov/pubmed/25714340.

18. Shrestha R, Wen YT, Ding DC, Tsai RK. Aberrant hiPSCsDerived from Human Keratinocytes Differentiates into 3D Retinal Organoids that Acquire Mature Photoreceptors. Cells. 2019;8(1):36. PMID: 30634512. Available from: https://doi.org/10.3390/cells8010036;http: //www.mdpi.com/2073-4409/8/1/36

19. Young MA, Larson DE, Sun CW, George DR, Ding L, Miller $C A$, et al. Background mutations in parental cells account for most of the genetic heterogeneity of induced pluripotent stem cells. Cell Stem Cell. 2012;10(5):570-582. PMID: 22542160. Available from: https://doi.org/10.1016/j.stem.2012. 03.002;http://www.ncbi.nlm.nih.gov/pubmed/22542160.

20. Kwon EM, Connelly JP, Hansen NF, Donovan FX, Winkler T, Davis BW, et al. iPSCs and fibroblast subclones from the same fibroblast population contain comparable levels of sequence variations. Proc Natl Acad Sci. 2017;114(8):1964-1969. PMID: 28167771. Available from: https://doi.org/10.1073/pnas. 1616035114;http://www.ncbi.nlm.nih.gov/pubmed/28167771.

21. Pera MF. The dark side of induced pluripotency. $\mathrm{Na}$ ture. 2011;471(7336):46-47. PMID: 21368819. Available from: https://doi.org/10.1038/471046a;http://www.ncbi. nlm.nih.gov/pubmed/21368819.

22. Peterson SE, Loring JF. Genomic instability in pluripotent stem cells: implications for clinical applications. J Biol Chem. 2014;289(8):4578-4584. PMID: 24362040. Available from: https://doi.org/10.1074/jbc.R113.516419;http: //www.ncbi.nlm.nih.gov/pubmed/24362040.

23. iPS Academia Japan. Company Profile / Our History;Available from: http://ips-cell.net/e/about/outline.html.

24. iPS Academia Japan. Our Licensees;Available from: http://ipscell.net/e/license/licensees.html.

25. Center for iPS Cell Research and Application (CiRA). Establishment of the new Center for iPS Cell Research and Application. 2010;Available from: http://www.cira.kyoto-u.ac.jp/e/ pressrelease/other/100305-182612.html.

26. Center for iPS Cell Research and Application (CiRA). Intellectual property of CIRA. 2018;Available from: https://www.cira. kyoto-u.ac.jp/e/research/special.html.

27. Sumitomo Dainippon Pharma. Sumitomo Dainippon Pharma Completes Manufacturing Plant for Regenerative Medicine \& Cell Therapy. 2018;Available from: https://www.ds-pharma. com/ir/news/2018/20180301-3.html

28. Fujita $Y$, Kawamoto A. Regenerative medicine legislation in Japan for fast provision of cell therapy products. Clin Pharmacol Ther. 2016;99(1):26-29. PMID: 26482927. Available from: https://doi.org/10.1002/cpt.279;http://www.ncbi. nlm.nih.gov/pubmed/26482927.

29. Cyranoski D. Japan to offer fast-track approval path for stem cell therapies. Nat Med. 2013;19(5):510-510. PMID: 23652082. Available from: https://doi.org/10.1038/nm0513510;http://www.nature.com/articles/nm0513-510.

30. Azuma K, Yamanaka S. Recent policies that support clinica application of induced pluripotent stem cell-based regenerative therapies. Regen Ther. 2016;4:36-47. PMID: 31245486. Available from: https://doi.org/10.1016/j.reth.2016.01.009; http: //www.ncbi.nlm.nih.gov/pubmed/31245486.

31. Cyranoski D. Japanese woman is first recipient of next-generation stem cells. Nature. 2014;Available from: $\quad$ https://doi.org/10.1038/nature.2014.15915;http: //www.nature.com/articles/nature.2014.15915.

32. Cyranoski D. Reprogrammed stem cells implanted into patient with Parkinson's disease. Nature. 2018;Available from: https://doi.org/10.1038/d41586-018-07407-9;http: //www.nature.com/articles/d41586-018-07407-9.

33. Cyranoski D. Reprogrammed stem cells approved to mend human hearts for the first time. Nature. 2018:557(7707):619-620. PMID: 29844563. Available from: https://doi.org/10.1038/d41586-018-05278-8;http //www.nature.com/articles/d41586-018-05278-8.

34. The Asahi Shimbun. Japan to begin world's 1st study of platelets made from iPS cells;Available from: 2018; http://www. asahi.com/ajw/articles/AJ201809220047.html.

35. Cyranoski D. Reprogrammed stem cells to treat spinalcord injuries for the first time. Nature. 2019;Available from: https://doi.org/10.1038/d41586-019-00656-2;http: //www.nature.com/articles/d41586-019-00656-2.

36. Cyranoski D. Japan poised to allow 'reprogrammed' stemcell therapy for damaged corneas. Nature. 2019;Available from: https://doi.org/10.1038/d41586-019-00860-0;http: //www.nature.com/articles/d41586-019-00860-0.

37. The Japan Times. Japanese team plans to use iPS cells in clinical trial for cancer patients. 2019;Available from: https://www.japantimes.co.jp/news/2019/01/11/national/ science-health/japanese-team-plans-use-ips-cells-clinicaltrial-cancer-patients/\#.XSZFa5NKgWq. 
38. Kyoto University. Drug candidate discovered using iPS cells now in clinical trial (1 August 2017). 2017;Available from: https://www.kyoto-u.ac.jp/en/research/events_news/ department/hospital/news/2017/170801_1.html.

39. RIKEN. Key regulatory hurdle cleared in planned iPS cell clinical research. 2013;Available from: http://www.riken.jp/en/pr/ topics/2013/20130628_1/.

40. RIKEN. Pilot clinical study into iPS cell therapy for eye disease starts in Japan. 2013;Available from: http://www.riken.jp/en/ pr/press/2013/20130730_1/.

41. Reardon S, Cyranoski D. Japan stem-cell trial stirs envy. Nature. 2014;513(7518):287-288. Available from: https://doi.org/10.1038/513287aPMid:25230622;http: //www.ncbi.nlm.nih.gov/pubmed/25230622.

42. Mandai M, Kurimoto $Y$, Takahashi M. Autologous Induced Stem-Cell-Derived Retinal Cells for Macular Degeneration. N Engl J Med. 2017;377(8):792-793. Available from: https://doi.org/10.1056/NEJMc1706274;http: //www.ncbi.nlm.nih.gov/pubmed/28834478.

43. Cyranoski D. Japanese man is first to receive "reprogrammed" stem cells from another person. Nature. 2017;Available from: https://doi.org/10.1038/nature.2017.21730; http://www. nature.com/articles/nature.2017.21730.

44. RIKEN. The RIKEN Venture System;Available from: http://www. riken.jp/en/outreach/ventures/.

45. Healios KK. iPSC Regenerative Medicine Field;Available from: https://www.healios.co.jp/en/development/ipsc/.

46. National Institute of Health (NIH). A Study of CYP-001 for the Treatment of Steroid-Resistant Acute Graft Versus Host Disease;Available from: https://clinicaltrials.gov/ct2/ show/NCT02923375.

47. Cell Culture Dish. First In-Human Allogeneic Clinical Trial Commences with iPSC-derived Mesenchymal Stem Cells. 2017; Available from: https://cellculturedish.com/first-inhuman-allogeneic-clinical-trial-commences-with-ipscderived-mesenchymal-stem-cells/.

48. Youssef AA, Ross EG, Bolli R, Pepine CJ, Leeper NJ, Yang PC. The Promise and Challenge of Induced Pluripotent
Stem Cells for Cardiovascular Applications. JACC Basic to Transl Sci. 2016;1(6):510-523. PMID: 28580434. Available from: https://doi.org/10.1016/j.jacbts.2016.06.010; http://www. ncbi.nlm.nih.gov/pubmed/28580434.

49. Gore A, Li Z, Fung HL, Young JE, Agarwal S. AntosiewicZBourget J, et al. Somatic coding mutations in human induced pluripotent stem cells. Nature. 2011;471(7336):6367. PMID: 21368825. Available from: https://doi.org/10.1038/ nature09805; http://www.ncbi.nlm.nih.gov/pubmed/21368825.

50. Taylor CJ, Peacock S, Chaudhry AN, Bradley JA, Bolton EM. Generating an iPSC Bank for HLA-Matched Tissue Transplantation Based on Known Donor and Recipient HLA Types. Cell Stem Cell. 2012;11(2):147-152. PMID: 22862941. Available from: https://doi.org/10.1016/j.stem.2012.07.014;http:// www.ncbi.nlm.nih.gov/pubmed/22862941.

51. Nakatsuji N, Nakajima F, Tokunaga K. HLA-haplotype banking and iPS cells. Nat Biotechnol. 2008;26(7):739-740. PMID 18612291. Available from: https://doi.org/10.1038/nbt0708739; http://www.nature.com/articles/nbt0708-739.

52. Xu H, Wang B, Ono M, Kagita A, Fujii K, Sasakawa N, et al Targeted Disruption of HLA Genes via CRISPR-Cas9 Generates iPSCs with Enhanced Immune Compatibility. Cel Stem Cell. 2019;24(4):566-578. PMID: 30853558. Available from: https://doi.org/10.1016/j.stem.2019.02.005; http:// www.ncbi.nlm.nih.gov/pubmed/30853558.

53. Eagle-i. Making Invisible Resources Visible;Available from: https://www.eagle-i.net/.

54. hPSCreg. Human Pluripotent Stem Cell Registry;Available from: https://hpscreg.eu/.

55. RIKEN. RIKEN BioResource Research Center;Available from: https://en.brc.riken.jp/.

56. SKiP Stemcell Database. Stemcell Knowledge \& Information Portal;Available from: https://skip.stemcellinformatics.org/en/. 57. Wataru Fujibuchi. Integrated Collection of Stem Cell Bank data by MIACARM. 2019;Available from: http://icscb.stemcellinformatics.org/. 